\title{
Comparison of the phytochemical profiles of five native plant species in two different forest formations
}

\author{
D. M. Pilatti ${ }^{a}$, A. M. T. Fortes ${ }^{b}$, T. C. M. Jorge and N. P. Boiago $^{d}$ \\ a Grupo de Pesquisa Plasticidade Fenotípica em Plantas, Laboratório de Ecologia Molecular e Parasitologia Evolutiva, \\ Programa de Pós-graduação em Ecologia e Conservação, Departamento de Zoologia, Setor de Ciências Biológicas, \\ Universidade Federal do Paraná - UFPR, Av. Coronel. Francisco Heráclito dos Santos, 100, Jardim das Américas, \\ CEP 81530-000, Curitiba, PR, Brasil \\ ${ }^{\text {b} G r u p o ~ d e ~ P e s q u i s a ~ M o n i t o r a m e n t o ~ e ~ P r e s e r v a c ̧ a ̃ o ~ d e ~ E c o s s i s t e m a s, ~ L a b o r a t o ́ r i o ~ d e ~ F i s i o l o g i a ~ V e g e t a l, ~ P r o g r a m a ~ d e ~}$ \\ Pós-graduação em Conservação e Manejo de Recursos Naturais, Centro de Ciências Biológicas e da Saúde, Universidade \\ Estadual do Oeste do Paraná - Unioeste, Rua Universitária, 2069, Universitário, CEP 85819-110, Cascavel, PR, Brasil \\ 'Grupo de Pesquisa Prospecção de Microrganismos e Substâncias Bioativas com Aplicações em Saúde, Laboratório de \\ Química, Centro de Ciências Médicas e Farmacêuticas, Universidade Estadual do Oeste do Paraná - Unioeste, \\ Rua Universitária, 2069, Universitário, CEP 85819-110, Cascavel, PR, Brasil \\ ${ }^{\text {d} G r u p o ~ d e ~ P e s q u i s a ~ d e ~ O t i m i z a c ̧ a ̃ o ~ d e ~ S i s t e m a s ~ A g r o i n d u s t r i a i s ~ d o ~ O e s t e ~ d o ~ P a r a n a ́, ~ L a b o r a t o ́ r i o ~ d e ~ C o n t r o l e ~ d e ~ q u a l i d a d e ~}$ \\ de produtos agrícolas, Programa de Pós-graduação em Engenharia Agrícola, Centro de Ciências Exatas e Tecnológicas, \\ Universidade Estadual do Oeste do Paraná - Unioeste, Rua Universitária, 2069, Universitário, CEP 85819-110, \\ Cascavel, PR, Brasil \\ *e-mail:dmpilatti@hotmail.com
}

Received: May 4, 2017 - Accepted: November 16, 2017 - Distributed: May 31, 2019

(With 1 figure)

\begin{abstract}
The expression of chemical compounds by individual plants of the same species in different locations may be affected by abiotic factors resulting in differences in the production of allelopathic compounds. The objective of this study was to compare the phytochemical profiles of plant species from two different forest formations in the state of Paraná, Brazil. The forest formations were Seasonal Semideciduous Forest (SSF) and Lowland Ombrophilous Dense Forest (LODF), and the five study species were Jacaranda micrantha, Cecropia pachystachya, Mimosa bimucronata, Schinus terebinthifolius and Cedrela fissilis. Secondary metabolites were extracted by exhaustive extraction with methanol, and the crude extract was fractionated using column chromatography. The fractions were used to calculate the retention factor of the main compounds using thin layer chromatography and phytochemical tests. The classes of compounds identified were practically the same among the analyzed species, however, at different levels of concentration. The type of tannins found in S. terebinthifolius differed between the two forest formations.
\end{abstract}

Keywords: allelopathy, plant ecophysiology, secondary metabolism, ecological succession.

\section{Comparação do perfil fitoquímico de cinco espécies vegetais provenientes de duas formações florestais diferentes}

\begin{abstract}
Resumo
A expressão de compostos químicos de uma mesma espécie pode ser afetada e diferenciada pelos fatores abióticos, resultando em respostas alelopáticas diferenciadas. O objetivo deste trabalho foi comparar o perfil químico de espécies provenientes de duas Formações Florestais do Estado do Paraná. As formações foram a Floresta Estacional Semidecidual e Floresta Ombrófila Densa, sendo as espécies escolhidas: Jacaranda micrantha, Cecropia pachystachya, Mimosa bimucronata, Schinus terebinthifolius e Cedrela fissilis. Foi realizada extração exaustiva dos metabólitos secundários com metanol e o extrato bruto fracionado em coluna cromatográfica. As frações foram utilizadas para calcular o fator de retenção dos constituintes principais empregando cromatografia em camada delgada e para realizar testes fitoquímicos. As classes de compostos identificados foram praticamente as mesmas entre as espécies analisadas, porém, em diferentes níveis de concentração. O tipo de tanino encontrado em S. terebinthifolius foi diferente entre as duas formações florestais.
\end{abstract}

Palavras-chave: alelopatia, ecofisiologia vegetal, metabolismo secundário, sucessão ecológica. 


\section{Introduction}

Plants are sessile organisms that communicate with their surroundings by releasing chemical compounds that originate from secondary metabolism. Interactions between animal pollinators and dispersal agents are made possible by the action of these compounds, as well as the interactions between plants themselves, which may or may not be of the same species (Taiz and Zeiger, 2013). Such chemical signaling between plants is called allelopathy, and was defined by Rice (1984) as "any effect, direct or indirect, beneficial or harmful, from one plant to another through the release of chemicals into the environment".

Such metabolic compounds can significantly influence the sequence and rate of species occurrence during plant succession (Whittaker and Feeny, 1971), as well as the species composition of a stable community. Maraschin-Silva and Aquila (2005) state that allelopathy affects all successional stages, the formation of plant communities, the dynamics between different formations and the dominance of certain species, thus affecting local biodiversity. Phenomena such as the rapid disappearance of pioneer species (Rice, 1984), a long duration of intermediate successional stages and the reversing of secondary successional stages in forestry have been associated with the production of allelochemicals (Mallik et al., 1998). Indeed, the vegetation of a particular area may have a succession model conditioned by pre-existing allelopathic plants (Ferreira and Áquila, 2000).

Allelopathy should not be neglected in efforts of artificial regeneration. The goal of these efforts is to create an ecosystem as similar as possible to the original one by providing renewable biodiversity conditions in which regenerating species are able to become self-sustaining and reproduce. This is necessary to ensure the genetic diversity of their populations and enabling the continued evolution of the species (Araki, 2005). Interference by potentially allelopathic substances can act directly or indirectly on these requirements, leading to the failure of such efforts.

Despite the genetics of any individual species, the expression of allelopathic compounds is susceptible to modifications from interactions with their habitat, such as variation in temperature, quality and quantity of light, water conditions, nutritional status and the presence of soil microorganisms. Thus, allelopathic effects result from a complex interaction between genetic and environmental factors (Rodrigues et al., 1999; Chou, 1999; Kutchan, 2001; Gobbo-Neto and Lopes, 2007; Gatti et al., 2014).

Thus, individuals of the same plant species may have their allelopathic characteristics determined by the abiotic characteristics of the forest formation in which they are inserted. Therefore, it is necessary to understand and predict such responses in order to avoid problems from chemical interference between species selected for models of artificial forestry recovery.

The most common bioassays performed regarding allelopathy address germination and the early development of plants submitted to different concentrations of allelochemicals. However, phytochemical profiles of these compounds can be of great value for determining the specific compounds responsible for allelopathic effects.
The purpose of this study was to compare the phytochemical profiles of five native species, which have been recommended for restoration of degraded areas, in two different forest formations in the state of Paraná, Brazil [Jacaranda micrantha Cham., Cecropia pachystachya Trécul, Mimosa bimucronata (DC.) Kuntze, Schinus terebinthifolius Raddi and Cedrela fissilis Vell.], in order to determine any differences in the composition of secondary metabolites, that may have allelopathic action in field.

\section{Material and Methods}

Species chosen for study needed to be: (a) native, (b) recommended for environmental restoration programs, and (c) occur in more than one forest formation (Carpanezzi and Carpanezzi, 2006; Borgo et al., 2011; Gris et al., 2012). Three of the species chosen were pioneer species (Jacaranda micrantha Cham. Bignoniaceae, Cecropia pachystachya Trécul - Urticaceae, Mimosa bimucronata (DC.) Kuntze - Fabacea), and two were early secondary species (Schinus terebinthifolius Raddi-Anacardiaceae e Cedrela fissilis Vell. - Meliaceae). Plant samples were collected and deposited in the UNOP herbarium - Herbário da Universidade Estadual do Oeste do Paraná,of the Universidade Estadual do Oeste do Paraná, Brazil.

\subsection{Plant material}

The plants used in this study were collected from two forest formations in the Atlantic Forest biome: Seasonal Semideciduous Forest - SSF (located in the Iguassu National Park) and Lowland Ombrophilous Dense Forest LODF (located in a private forest reserve of the Society of Wildlife Research and Environmental Education, SPVS), both in southern Brazil.

Leaves were collected from a minimum of three individuals of each species at the same developmental stage (greater than $15 \mathrm{~cm}$ circumference at breast height; $\mathrm{CBH}$ ).

Leaves were dried in a circulating-air oven at $30{ }^{\circ} \mathrm{C}$, until their dry weight remained stable. The plant material was then grounded in a Willey knife mill with a $10 \mathrm{~mm}$ granulation sieve. Samples were then stored in labeled glass jars and kept at room temperature and protected from light.

\subsection{Crude extract preparation}

Crude extract was prepared using methanol P.A. as the main solvent at $100 \mathrm{gL}^{-1}$ (weight/volume). Plant material was mixed with the solvent and left in static maceration at room temperature with the absence of light for 10 days.

The extraction solution was then filtered through filter paper on the tenth day, and the filtrate transferred to a flask and concentrated in a rotatory evaporator. After the complete removal of the solvent, the crude extract was refrigerated until bioassays were performed.

\subsection{Crude extract fractionation}

Crude extract was fractionated using a $50 \mathrm{~mL}$ fractionating column and $20 \mathrm{~g}$ silica gel $\mathrm{Vetec}^{\circledR}$ as a stationary phase with chloroform P.A as eluent. A sample of $2 \mathrm{~g}$ of crude extract of each plant species was fractionated on the chromatography column using $50 \mathrm{~mL}$ of the following eluents in increasing 
polarity: methanol $(\mathrm{MeOH})$ 1:3 chloroform $\left(\mathrm{CHCl}_{3}\right)$, $\mathrm{MeOH} 2: 1 \mathrm{CHCl}_{3}$ and only $\mathrm{MeOH}$. In each column, the extract was separated into five fractions, differing from each other by their color. The solvent was evaporated from each fraction at room temperature.

The chromatographic profile of each extract was assessed for the presence of alkaloids, terpenes and phenolic compounds by phytochemical bioassays based on colorimetric reactions.

\subsection{Chromatographic profile by Thin Layer Chromatography (TLC)}

For the preparation of chromatograms, Silica gel Carvalhes ${ }^{\circledR}$ was used diluted in distilled water and dried at $50{ }^{\circ} \mathrm{C}$. Samples of fractionated crude extract of each plant species were dissolved in methanol and applied to a TLC plate with a capillary tube; ethanol:chloroform (70:30) was used as eluent.

After obtaining the chromatograms, the retention factor $\left(R_{f}\right)$ was calculated by the following formula: $R_{f}=h / H$, where $\mathrm{R}_{\mathrm{f}}=$ retention factor; $\mathrm{h}=$ distance covered by the substance and $\mathrm{H}=$ distance covered by the eluent.
Both chromatographic methods were adapted from Collins et al. (1997).

\subsection{Phytochemical tests}

Some substances invisible to TLC can be identified by phytochemical assay based on colorimetric reactions. Phytochemical tests for each species and from both forest formations, were performed using the crude extract and the five fractions for each, following Barbosa et al. (2001). Extracts were tested for alkaloids, phenolic compounds (phenols, water-soluble tannins, condensed tannins, anthocyanins, flavones and xanthones, chalcones and auronas, flavonols) and terpenes (saponins, steroids and triterpenoids).

Results are recorded as low (-), moderate $(++)$ or strong $(+++)$, depending on the concentration. The absence of a chemical compound is not categorized, and a low concentration can be represented by negative results.

\section{Results and Discussion}

Pigments are present in the first fractions obtained from the chromatographic column (fraction 1 and 2) for all species, as shown in Figure 1 where darker spots correspond
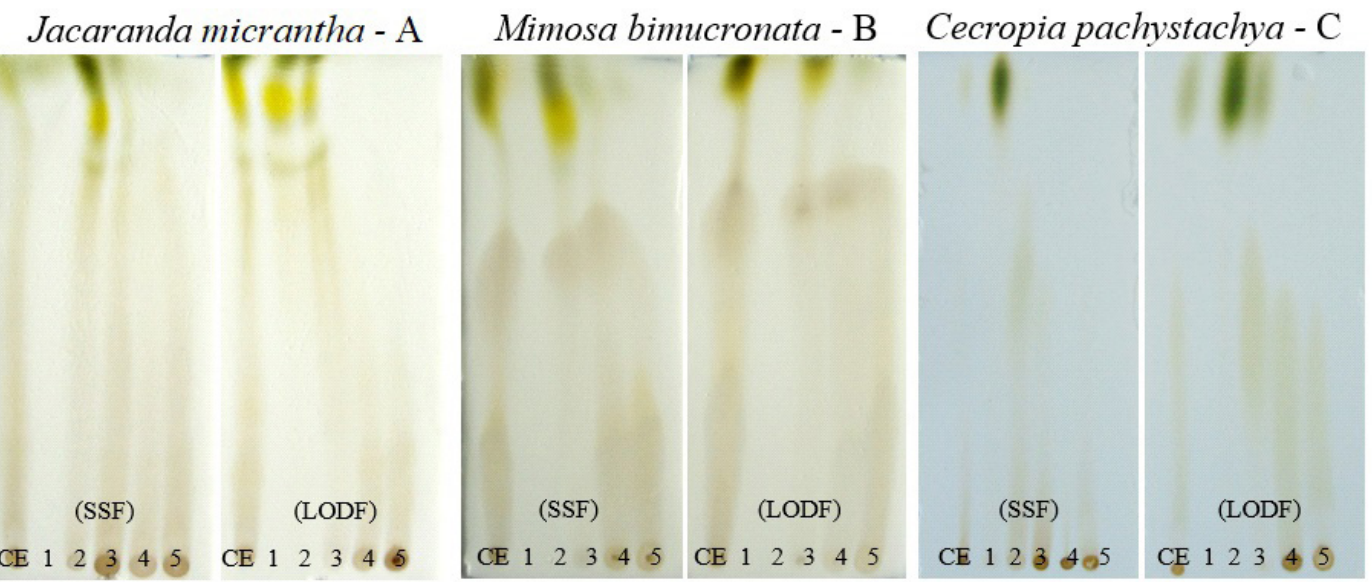

\section{Schinus terebinthifolius - D}
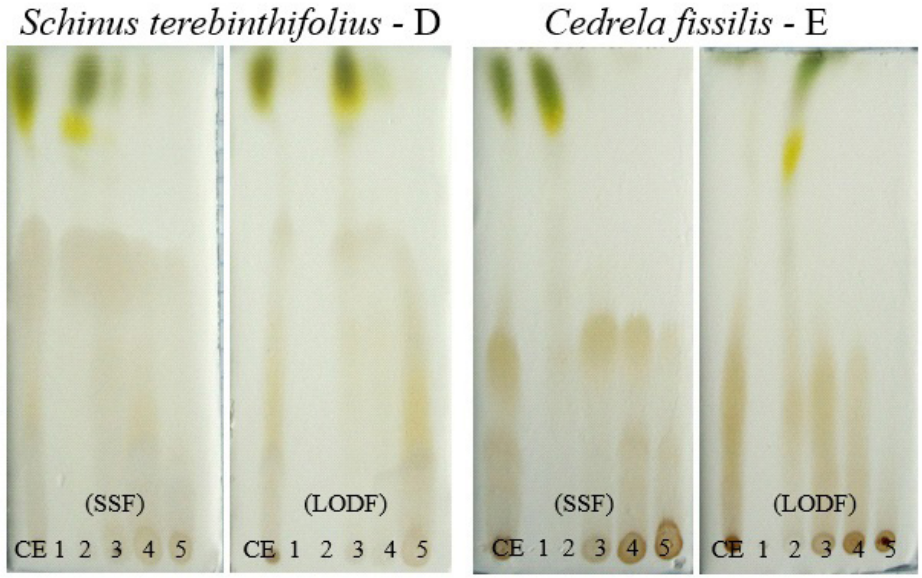

Figure 1. Thin layer chromatography of methanolic extract of five species from Seasonal Semideciduous Forest (SSF) and Lowland Ombrophilous Dense Forest (LODF). CE represent crude extract and numbers 1 to 5 represent extract fractions. 
to chlorophyll and lighter spots nearby to xanthophyll. Both pigments are extremely important in photosynthesis and their concentration must be considered, since an increase or decrease in the processes of photosynthesis may indirectly influence the production of secondary metabolites, whose synthesis depends on primary metabolic products (Souza et al., 2011).

\subsection{Jacaranda micrantha}

Analysis of the methanolic crude extract of J. micrantha (Figure 1A), revealed a difference in the concentration of substances among fractions 1 and 3 and between Seasonal Semideciduous Forest (SSF) and Lowland Ombrophilous Dense Forest (LODF), with a darker spot in the LODF chromatogram.

This result is related to the first stops, which suggest higher concentrations of chlorophyll and xanthophyll, both high molecular weight pigments from the terpenes group. In the LODF chromatogram, this pigment appears only in fraction 2.

Table 1 shows positive results for the three major groups of secondary compounds: alkaloids, phenolic compounds and terpenes. The alkaloid test indicated higher concentrations for fractions 4 and 5 for the SSF extract in comparison with the LODF extract, which besides having lower concentrations of these compounds, was positive only for the $5^{\text {th }}$ fraction.

For phenolic compounds, condensed tannins were identified in all fractions except fraction 1, while the SSF extract fractions exhibited lower concentrations of condensed tannins than the LODF extract. We also identified chalcones and aurones with no difference between the extracts from the two forest formations.

Tests for terpenes quantified higher concentrations of saponins, steroids and triterpenoids in the LODF extract, with the exception of fraction 1 , which was positive for steroids and triterpenoids in SSF but negative for these in LODF.
Martins et al. (2008) also found tannins, phytoquinoids and probably the presence of flavonoids in J. micrantha extract, with phytoquinoids being the most abundant. These compounds are related to defense against herbivores and pathogens, pollination, dispersal and allelopathy. Same authors confirmed the presence of steroids, triterpenes and saponins in the genus Jacaranda. Subramanian et al. (1973) also found the phenol hydroquinone in Jacaranda mimosaefolia, while Santos et al. (2010a) found several types of aldehydes and polyphenols in Jacaranda puberula.

\subsection{Mimosa bimucronata}

In the chromatogram for M. bimucronata (Figure 1B), a slight difference in the height of the spots of chlorophyll and xanthophyll between crude extracts can be seen. Fractions 1 and 2 do not appear in the chromatography test, nor were they sufficient to detect compounds in phytochemical tests. Fraction 3 has the same retention factor for the two locations studied, which differed in the other fractions (Table 2).

Fractions 4 and 5 for the SSF extract were negative for the presence of alkaloids and have retention factors of 0.29 and 0.13 , respectively. For LODF extract, fractions 4 and 5 were positive for presence of alkaloids, which probably explains why the retention factor for the LODF extract was higher than that for the SSF extract.

Hydrolysable tannins and flavonoids appear to occur in the same concentrations in both forest formations, with the exception of fractions 1 and 2. The saponin test showed homogeneity in the occurrence of this substance among SSF extract fractions and differences among the LODF extract fractions. The test for steroids and triterpenoids was negative for fraction 5 of the SSF extract and positive for LODF extract, but in low concentration.

Tannins have also been found in Mimosa arenosa and Mimosa tenuiflora (Paes et al., 2006), however, with higher concentrations in the bark. Jacobi and Ferreira (1991) found a high concentration of tannins in the leaves

Table 1. Phytochemical test for different classes of compounds of methanolic extract of Jacaranda micrantha from Seasonal Semideciduous Forest and Lowland Ombrophilous Dense Forest. CE represents crude extract and numbers 1 to 5 represent extract fractions. Rf represents retention factor.

\begin{tabular}{|c|c|c|c|c|c|c|c|c|c|c|c|c|}
\hline \multirow{2}{*}{ Compounds } & \multicolumn{6}{|c|}{ Seasonal Semideciduous Forest } & \multicolumn{6}{|c|}{ Lowland Ombrophilous Dense Forest } \\
\hline & $\mathbf{C E}$ & 1 & 2 & 3 & 4 & 5 & $\mathbf{C E}$ & 1 & 2 & 3 & 4 & 5 \\
\hline alkaloids & - & - & - & - & +++ & ++ & - & - & - & - & - & ++ \\
\hline phenols & - & - & - & - & - & - & - & - & - & - & - & - \\
\hline water-soluble tannins & - & - & - & - & - & - & - & - & - & - & - & - \\
\hline condensed tannins & +++ & - & + & + & +++ & +++ & ++ & - & ++ & +++ & +++ & +++ \\
\hline anthocyanins & - & - & - & - & - & - & - & - & - & - & - & - \\
\hline flavones/xanthones & - & - & - & - & - & - & - & - & - & - & - & - \\
\hline chalcones/auronas & +++ & - & +++ & +++ & +++ & +++ & +++ & - & +++ & +++ & +++ & +++ \\
\hline flavonols & - & - & - & - & - & - & - & - & - & - & - & - \\
\hline saponins & ++ & - & + & ++ & ++ & ++ & +++ & - & +++ & +++ & +++ & +++ \\
\hline steroids/triterpenoids & +++ & + & +++ & ++ & - & - & +++ & - & +++ & ++ & - & - \\
\hline $\mathbf{R}_{\mathrm{f}}$ & 0.5 & 0.5 & 0.5 & 0.5 & 0.29 & 0.19 & 0.45 & 0 & 0.5 & 0.43 & 0.38 & 0.42 \\
\hline
\end{tabular}

Results are recorded as low (-), moderate (++) or strong (+++), depending on the concentration. 
of Mimosa bimucronata, noting that the concentration of these allelopathic compounds increases concomitantly with the level of maturity of the leaves; it seems that when the leaves are dried the allelopathic potential increases because the membranes are easily broken when dehydrated, leading to the release of these compoundsinto the environment.

Mimosa bimucronata is deciduous and may have high allelopathic potential once the leaves degrade in the soil, but this needs further investigation.

\subsection{Cecropia pachystachya}

As can be seen in Figure 1C, the pigment content of C. pachystachya differs between the two forests with greater pigment in the SSF extract, which had a higher chlorophyll content. The other spots are also more visible in this forest chromatogram and its retention factor demonstrates the higher concentration of compounds compared to fractions obtained from leaves collected in the LODF (Table 3).
The first fraction of C. Pachystachya SSF extract was negligible for all parameters, while the same fraction for LODF extract had a retention factor of 0.5 and showed pigments all the way to the end of the chromatogram (Figure 1C). When fractions are separated in a chromatography column, compounds are separated by forces acting on the stationary and mobile phases; if these compounds occur in different concentrations in different forests plants, their separation will also be different, resulting in unequal fractions and different groupings of substances.

The alkaloid test was positive for the both forests extracts, with the SSF extract having a higher concentration, as can be seen in fraction 2 and 3 (Table 3). Condensed tannins were more homogeneously distributed among the LODF extract fractions, in addition to being positive in fraction 1, unlike the SSF extract. Flavonoids and saponins had their highest concentrations in the fractions of the extract from LODF. Steroids and triterpenoids were observed in

Table 2. Phytochemical test for different classes of compounds of methanolic extract of Mimosa bimucronata from Seasonal Semideciduous Forest and Lowland Ombrophilous Dense Forest. CE represents crude extract and numbers 1 to 5 represent extract fractions. $\mathrm{Rf}$ represents retention factor.

\begin{tabular}{|c|c|c|c|c|c|c|c|c|c|c|c|c|}
\hline \multirow{2}{*}{ Compounds } & \multicolumn{6}{|c|}{ Seasonal Semideciduous Forest } & \multicolumn{6}{|c|}{ Lowland Ombrophilous Dense Forest } \\
\hline & $\mathbf{C E}$ & 1 & 2 & 3 & 4 & 5 & $\mathbf{C E}$ & 1 & 2 & 3 & 4 & 5 \\
\hline alkaloids & - & - & - & - & - & - & - & - & - & - & ++ & +++ \\
\hline phenols & - & - & - & - & - & - & - & - & - & - & & - \\
\hline water-soluble tannins & +++ & - & - & ++ & +++ & +++ & +++ & - & - & +++ & +++ & +++ \\
\hline condensed tannins & - & - & - & - & - & - & - & - & - & - & - & - \\
\hline anthocyanins & - & - & - & - & - & - & - & - & - & - & - & - \\
\hline flavones/xanthones & - & - & - & - & - & - & - & - & - & - & - & - \\
\hline chalcones/auronas & - & - & - & - & - & - & - & - & - & - & - & - \\
\hline flavonols & ++ & - & - & ++ & ++ & +++ & ++ & - & - & +++ & ++ & ++ \\
\hline saponins & ++ & - & - & ++ & ++ & ++ & +++ & - & - & ++ & + & + \\
\hline steroids/triterpenoids & +++ & - & - & +++ & + & - & ++ & - & - & +++ & ++ & + \\
\hline $\mathbf{R}_{\mathrm{f}}$ & 0.5 & - & - & 0.5 & 0.29 & 0.13 & 0.5 & - & - & 0.5 & 0.38 & 0.38 \\
\hline
\end{tabular}

Results are recorded as low (-), moderate (++) or strong (+++), depending on the concentration.

Table 3. Phytochemical test for different classes of compounds of methanolic extract of Cecropia pachystachya from Seasonal Semideciduous Forest and Lowland Ombrophilous Dense Forest. CE represents crude extract and numbers 1 to 5 represent extract fractions. Rf represents retention factor.

\begin{tabular}{|c|c|c|c|c|c|c|c|c|c|c|c|c|}
\hline \multirow{2}{*}{ Compounds } & \multicolumn{6}{|c|}{ Seasonal Semideciduous Forest } & \multicolumn{6}{|c|}{ Lowland Ombrophilous Dense Forest } \\
\hline & $\mathbf{C E}$ & 1 & 2 & 3 & 4 & 5 & $\mathbf{C E}$ & 1 & 2 & 3 & 4 & 5 \\
\hline alkaloids & - & - & + & ++ & - & - & - & - & + & - & - & - \\
\hline phenols & - & - & - & - & - & - & - & - & - & - & - & - \\
\hline water-soluble tannins & - & - & - & - & - & - & - & - & - & - & - & - \\
\hline condensed tannins & +++ & - & + & + & ++ & + & ++ & + & ++ & ++ & ++ & ++ \\
\hline anthocyanins & - & - & - & - & - & - & - & - & - & - & - & - \\
\hline flavones/xanthones & - & - & - & - & - & - & - & - & - & - & - & - \\
\hline chalcones/auronas & - & - & - & - & - & - & - & - & - & - & - & - \\
\hline flavonols & +++ & - & + & + & ++ & + & +++ & + & ++ & ++ & ++ & ++ \\
\hline saponins & +++ & - & ++ & - & ++ & - & +++ & - & ++ & ++ & ++ & ++ \\
\hline steroids/triterpenoids & ++ & - & +++ & + & - & - & ++ & +++ & - & - & - & - \\
\hline $\mathbf{R}_{\mathrm{f}}$ & 0.5 & - & 0.5 & 0.5 & 0.27 & 0.25 & 0.5 & 0.5 & 0.36 & 0.31 & 0.11 & 0.27 \\
\hline
\end{tabular}

Results are recorded as low (-), moderate $(++)$ or strong $(+++)$, depending on the concentration. 
three fractions of the SSF extract, and only two fractions of the LODF extract.

Studies with C. Pachystachya (Simões and Minguzzi, 2009) have previously demonstrated the presence of primary and secondary metabolites, such as reducing sugars, proteins, amino acids, coumarin derivatives and tannins. Another study carried out with methanol extract of this species (Aragão, 2009) points to the presence of alkaloids, phenolics, such as flavonoids and anthocyanins, tannins and steroids.

Stange et al., (2009) performed phytochemical tests on a species of the genus Cecropia, C. glaziovii, and found tannins, flavonoids, phenols, anthraquinones, coumarins, catechins, proteins, reducing sugars, depsides and triterpenes, corroborating the results of Tanae et al., (2007) for the same species and Rocha et al., (2007) for C. lyratiloba.

Stange et al. (2009) observed the absence of toxicity in Cecropia extract and related this to the absence of alkaloids. Tannins and flavonoids also found by these authors showed no effect on Allium cepa; it is probable that the concentrations used were not sufficient to cause an allelopathic effect. This observation, combined with the absence of alkaloids, indicates that species of Cecropia are promising candidates for plant restoration, but laboratory and field tests are still needed.

The low concentration of secondary compounds in this species may be associated with the fact that it is a mymercophyte species (Mundim et al., 2012), that is, have a relationship of mutualism with ants that, in exchange for shelter, protect the plant from exposure to herbivores. Since the protection of the plant is done by another species, it is probable that it does not need to defend itself chemically and thus, defense compounds are produced on a low scale in the species. Indeed, this relationship with herbivory was observed in young leaves of Blepharocalyx salicifolius, that do not have defense mechanisms against herbivores. These young leaves produce high concentrations of secondary metabolites to compensate for the absence of these structures (Habermann et al., 2016).

\subsection{Schinus terebinthifolius}

Schinus terebinthifolius extract from LODF had greater pigmentation than the SSF extract, including xanthophyll (Figure 1D). Alkaloids occurred in low concentrations, appearing in only one fraction, which suggests that this species does not produce an allelopathic effect with this class of compounds.

Phenolic tests showed differences between forests formations for S. terebinthifolius. Extract of S. terebinthifolius from LODF was positive for hydrolysable tannins, while SSF extract was positive for condensed tannins. This qualitative difference between phenolic compounds was observed only in this species among the five studied in this work (Table 4).

These two types of tannins have different metabolic routes with hydrolysable tannins being formed from shikimate (Monteiro et al., 2005) and condensed tannins being the products of phenylpropanol metabolism (Heil et al., 2002).

Hydrolysable tannins regulate peroxidase activity, are found in fruits, such as strawberry (Fragaria spp), black currant (Ribes nigrum), blackberry (Rubus subgenus Eubatus), raspberry (Rubus subgenus Idaeobatus), among other species (Antunes, 2002). These compounds have allelopathic potential because they inhibit the germination of seeds, affect nitrogen fixation and limit plant growth (Barbosa et al., 2008)

Condensed tannins have high molecular weights and are also called proanthocyanidins because they possess red anthocyanidin pigments (Castejon, 2011). They occur in large concentrations in some fruits (grapes and apples), cocoa and chocolate (Santos-Buelga and Scalbert, 2000) and have proven allelopathic potential (Whittaker and Feeny, 1971).

The differences between these compounds may be related to phenotypic plasticity, which is characteristic of

Table 4. Phytochemical test for different classes of compounds of methanolic extract of Schinus terebinthifolius from Seasonal Semideciduous Forest and Lowland Ombrophilous Dense Forest. CE represents crude extract and numbers 1 to 5 represent extract fractions. Rf represents retention factor.

\begin{tabular}{|c|c|c|c|c|c|c|c|c|c|c|c|c|}
\hline \multirow{2}{*}{ Compounds } & \multicolumn{6}{|c|}{ Seasonal Semideciduous Forest } & \multicolumn{6}{|c|}{ Lowland Ombrophilous Dense Forest } \\
\hline & $\mathbf{C E}$ & 1 & 2 & 3 & 4 & 5 & $\mathbf{C E}$ & 1 & 2 & 3 & 4 & 5 \\
\hline alkaloids & - & - & - & - & - & + & - & - & - & + & - & - \\
\hline phenols & - & - & - & - & - & - & - & - & - & - & - & - \\
\hline water-soluble tannins & - & - & - & - & - & - & +++ & - & ++ & +++ & +++ & +++ \\
\hline condensed tannins & +++ & - & - & ++ & ++ & +++ & - & - & - & - & - & - \\
\hline anthocyanins & - & - & - & - & - & - & - & - & - & - & - & - \\
\hline flavones/xanthones & - & - & - & - & - & - & - & - & - & - & - & - \\
\hline chalcones/auronas & - & - & - & - & - & - & - & - & - & - & - & - \\
\hline flavonols & +++ & - & - & + & ++ & +++ & +++ & - & ++ & ++ & +++ & +++ \\
\hline saponins & ++ & - & - & + & ++ & + & +++ & - & + & + & ++ & + \\
\hline steroids/triterpenoids & ++ & - & ++ & - & + & - & + & ++ & - & +++ & - & - \\
\hline $\mathbf{R}_{\mathrm{f}}$ & 0.5 & - & - & 0.5 & 0.5 & 0.3 & 0.5 & - & 0.5 & 0.5 & 0.5 & 0.28 \\
\hline
\end{tabular}

Results are recorded as low $(-)$, moderate $(++)$ or strong $(+++)$, depending on the concentration. 
this species, and which is defined as the ability of a plant to adapt to the environment in which it is inserted through changes in functional and/or structural characteristics (Sabbi et al., 2010). As the two studied forest formations possess their own climate peculiarities, such as differences in temperature, precipitation, humidity, soil formation, herbivores, pollinators and seed dispersers, it is possible that secondary metabolite production is influenced by these characteristics and reflect the best adaptation of the plant to a given environment.

The results for flavonoids were stronger for fractions of LODF than for SSF; they were present in fraction 2 of the LODF extract, suggesting a higher concentration of this compound for S. terebinthifolius from LODF. The results of the saponins test were similar for the two forest formations whereas tests for steroids and triterpenoids indicated higher concentrations for fractions of LODF extract.

Even with very similar retention factors, the fractions for S. terebinthifolius exhibited marked differences among each other in the concentrations of the tested compounds. This observation highlights the importance of performing tests concomitantly for the identification of secondary metabolites. The retention factor, Rf, when used in a comparative manner with a known standard substance, is a qualitative method used to identify compounds (Degani et al., 1998). However, the present work did not use standard substances for identifying substances, and $\mathrm{Rf}$ was used only in a comparative way between fractions from different forest formations. Since the value is the same, it is expected that the substances are also the same, but the results with S. terebinthifolius shown that this is not always the case, since the identified tannins were different in the individuals from the two different forest formations.

Other phytochemical studies indicate the presence of fatty acids and terpenoids, ethyl and methyl gallates, flavonol, miricetina and quercitrin, some of which are flavonoid precursors (Ceruks et al., 2007).
Flavonoids and tannins were also reported by Lawrence (1984), as quoted by Santos et al. (2008), and Queires and Rodrigues (1998). Santos et al. (2010b) identified $\alpha$-pinene and sabinene, which have bactericidal activity, in the essential oil of $S$. terebinthifolius (Shimizu et al., 2006), plus bicyclogermacrene, which has larvicide potential (Santos et al., 2006). These results suggest that these metabolites have a role in defense against herbivores and pathogens, and defense-related metabolites are known to also have allelopathic properties.

\subsection{Cedrela fissilis}

The chromatogram for C. fissilis is shown in Figure 1E, where it can be seen that there was a higher concentration of chlorophyll in the LODF extract, which exhibits this pigment in two fractions. The following fractions, fractions 3 and 4, appear to have approximately the same height; however, observing the retention factors in Table 5, a slight difference between the concentrations of the compounds tested can be seen. Fraction 4 of LOD extract was positive for steroids and triterpenoids.

Crude extract of C. fissilis was not positive for alkaloids, even in fraction 4 of both forests. This failure to detect alkaloids was probably because the phytochemical test is based on color and the crude extract is naturally very dark. This also occurred with other species in this work, highlighting the importance of the fractionation of crude extract for the identification of its constituent chemicals.

Matos (2006) also identified triterpenoids in Cedrela fissilis and, later, Matos et al. (2010) report an important triterpenoid in the genus Cedrela; limonoid, which has strong bioactivity against Lepidoptera. This compound was also reported by Leite et al. (2005), Ambrozin et al. (2006) and Barbosa et al. (2007).

Zavan (2005) investigated the insecticidal properties of Cedrela fissilis on leaf-cutting ants and isolated the flavonoid catechin, which is a condensed tannin and was also found in this work.

Table 5. Phytochemical test for different classes of compounds of methanolic extract of Cedrela fissilis from Seasonal Semideciduous Forest and Lowland Ombrophilous Dense Forest. CE represents crude extract and numbers 1 to 5 represent extract fraction. Rf represents retention factor.

\begin{tabular}{|c|c|c|c|c|c|c|c|c|c|c|c|c|}
\hline \multirow{2}{*}{ Compounds } & \multicolumn{6}{|c|}{ Seasonal Semideciduous Forest } & \multicolumn{6}{|c|}{ Lowland Ombrophilous Dense Forest } \\
\hline & $\mathbf{C E}$ & 1 & 2 & 3 & 4 & 5 & $\mathbf{C E}$ & 1 & 2 & 3 & 4 & 5 \\
\hline alkaloids & - & - & - & - & + & - & - & - & - & - & ++ & - \\
\hline phenols & - & - & - & - & - & - & - & - & - & - & - & - \\
\hline water-soluble tannins & - & - & - & - & - & - & - & - & - & - & - & - \\
\hline condensed tannins & ++ & - & ++ & +++ & +++ & +++ & +++ & - & +++ & +++ & +++ & +++ \\
\hline anthocyanins & - & - & - & - & - & - & - & - & - & - & - & - \\
\hline flavones/xanthones & - & - & - & - & - & - & - & - & - & - & - & - \\
\hline chalcones/auronas & +++ & - & ++ & +++ & +++ & +++ & +++ & - & + & ++ & +++ & ++ \\
\hline flavonols & - & - & - & - & - & - & - & - & - & - & - & - \\
\hline saponins & +++ & - & + & + & +++ & +++ & +++ & - & + & + & +++ & +++ \\
\hline steroids/triterpenoids & +++ & + & +++ & ++ & - & - & +++ & - & +++ & ++ & + & - \\
\hline $\mathbf{R}_{\mathrm{f}}$ & 0.5 & 0 & 0.5 & 0.22 & 0.19 & 0.09 & 0.5 & - & 0.5 & 0.28 & 0.22 & 0.21 \\
\hline
\end{tabular}

Results are recorded as low (-), moderate $(++)$ or strong $(+++)$, depending on the concentration. 


\section{Conclusion}

The phytochemical profiles of each species studied in this work differ between the two forest formations, and more so quantitatively than qualitatively, (i.e., the same chemicals are produced by the same species in different locations, varying only in concentration). Schinus terebinthifolius was the only species to exhibit a qualitative difference, since individuals collected in the Seasonal Semideciduous Forest possessed hydrolysable tannins, while individuals from Lowland Ombrophilous Dense Forest had condensed tannins.

Based on their chemical profiles, J. micrantha, C. pachystachya, M. bimucronata, S. terebinthifolius and C.fissilis can mediate natural allelopathic events; however, more studies must be performed in order to better understand the consequent allelopathic effects of the reported substances.

\section{References}

ANTUNES, L.E.C., 2002. Amora-preta: nova opção de cultivo no Brasil. Ciência Rural, vol. 32, no. 1, pp. 151-158. http://dx.doi. org/10.1590/S0103-84782002000100026.

AMBROZIN, A.R.P., LEITE, A.C., BUENO, F.C., VIEIRA, P.C., FERNANDES, J.B., BUENO, O.C., SILVA, M.F.G.F., PAGNOCCA, F.C., HEBLING, M.J.A. and BACCI JÚNIOR, M., 2006. Limonoids from andiroba oil and Cedrela fissilis and their insecticidal activity. Journal of the Brazilian Chemical Society, vol. 17, no. 3, pp. 542-547. http://dx.doi.org/10.1590/ S0103-50532006000300017.

ARAGÃO, D.M.O. 2009. Perfil químico do extrato metanólico de Cecropia pachystachya e seu potencial hipoglicemiante em ratos diabéticos induzidos por haloxano. Minas Gerais: Universidade Federal de Juiz de For a, 171 p. Dissertação de Mestrado em Ciências Biológicas.

ARAKI, D.F. 2005. Avaliação da semeadura a lanço de espécies florestais nativas para recuperação de áreas degradadas. Piracicaba: Escola superior de agricultura Luis de Queiroz, 150 p. Dissertação de Mestrado em Ecologia de Agroecossitesmas.

BARBOSA, A.P., NASCIMENTO, C.S. and MORAIS, J.W., 2007. Estudos de propriedades antitermíticas de extratos brutos de madeira e casca de espécies florestais da Amazônia Central, Brasil. Acta Amazonica, vol. 37, no. 2, pp. 213-218. http://dx.doi. org/10.1590/S0044-59672007000200006.

BARBOSA, C.S., MAIA, F. and SANTOS, D.Q and HERNANDEZ TERRONES, M.G., 2008. Potencial herbicida do extrato diclorometanólico de folha da lixeira (Curatella americana L.). In: Resumos do VIII Encontro Interno e XIII Encontro de Iniciação Cientifica, 2008, Uberlandia. Uberlândia: Universidade Federal de Uberlândia, pp. 1-9.

BARBOSA, W.L.R., QUINARD, E., TAVARES, I.C.C., PINTO, L.N., OLIVEIRA, F.Q. and OLIVEIRA, R.M. 2001. Manual para análise fitoquímica e cromatográfica de extratos vegetais. Belém, Universidade Federal do Pará.

BORGO, M., TIEPOLO, G., REGINATO, M., KUNIYOSHI, Y.S., GALVÃO, F., CAPRETZ, R.L. and ZWIENER, V.P., 2011. Espécies arbóreas de um trecho de floresta atlântica do município de Antonina, Paraná, Brasil. Floresta, vol. 41, no. 4, pp. 819-832. http://dx.doi.org/10.5380/rf.v41i4.25346.
CARPANEZZI, A.A. and CARPANEZZI, O.T.B., 2006 [viewed 15 October 2013]. Espécies nativas recomendadas para recuperação ambiental no Estado do Paraná, em solos não degradados [online]. Embrapa Florestas. Available from: http://www.infoteca.cnptia. embrapa.br/handle/doc/313946

CASTEJON, F.V., 2011 [viewed 15 October 2013]. Taninos e Saponinas [online]. Universidade Federal de Goiás. Available from: https://portais.ufg.br/up/67/o/semi2011_Fernanda_Castejon_1c.pdf

CERUKS, M., ROMOFF, P., FAVERO, A.O. and LAGO, G.J.H., 2007. Constituintes fenólicos polares de Schinus terebinthifolius Raddi (Anacardiaceae). Quimica Nova, vol. 30, no. 3, pp. 597-599. http://dx.doi.org/10.1590/S0100-40422007000300018.

CHOU, C.H., 1999. Roles of allelopathy in plant biodiversity and sustainable agriculture. Critical Reviews in Plant Sciences, vol. 18, no. 5, pp. 609-630. http://dx.doi.org/10.1080/07352689991309414.

COLLINS, C.H., BRAGA, G.L. and BONATO, P.S., 1997. Introdução a métodos cromatográficos. 7 ed. Campinas: Editora Unicamp, $279 \mathrm{p}$

FERREIRA, A.G. and AQUILA, M.E.A., 2000. Alelopatia: uma área emergente da ecofisiologia. Revista Brasileira de Fisiologia Vegetal, vol. 12, pp. 175-204. Número Especial.

GATTI, A.B., TAKAO, L.K., PEREIRA, V.C., FERREIRA, A.G., LIMA, M.I.S. and GUALTIERI, S.C.J., 2014. Seasonality effect on the allelopathy of cerrado species. Brazilian Journal of Biology $=$ Revista Brasileira de Biologia, vol. 74, no. 3, suppl. 1, pp. S64-69. http://dx.doi.org/10.1590/1519-6984.21512. PMid:25627367.

GOBBO-NETO, L. and LOPES, N.P., 2007. Plantas medicinais: fatores de influência no conteúdo de metabólitos secundários. Química Nova, vol. 30, no. 2, pp. 374-381. http://dx.doi.org/10.1590/ S0100-40422007000200026.

GRIS, D., TEMPONI, L.G. and MARCON, T.R., 2012. Native species indicated for degraded area recovery in Western Paraná, Brazil. Revista Árvore, vol. 36, no. 1, pp. 113-125. http://dx.doi. org/10.1590/S0100-67622012000100013.

HABERMANN, E., PONTES, F.C., PEREIRA, V.C., IMATOMI, M. and GUALTIERI, S.C.J., 2016. Phytotoxic potential of young leaves from Blepharocalyx salicifolius (Kunth) O. Berg (Myrtaceae). Brazilian Journal of Biology $=$ Revista Brasileira de Biologia, vol. 76, no. 2, pp. 531-538. http://dx.doi.org/10.1590/15196984.24114. PMid:26959947.

HEIL, M., BAUMANN, B., ANDARY, C., LINSENMAIR, K.E. and MCKEY, D., 2002. Extraction and quantification of "condensed tannins" as a measure of plant anti-herbivore defence? Revisiting an old problem. Naturwissenschaften, vol. 89, no. 11, pp. 519-524. http://dx.doi.org/10.1007/s00114-002-0366-3. PMid:12451456.

JACOBI, U.S. and FERREIRA, A.G., 1991. Efeitos alelopáticos de Mimosa bimucronata (DC) OK. sobre espécies cultivadas. Pesquisa Agropecuária Brasileira, vol. 26, no. 7, pp. 935-943.

KUTCHAN, T.M., 2001. Ecological arsenal and developmental dispatcher. The paradigm of secondary metabolism. Plant Physiology, vol. 125, no. 1, pp. 58-60. http://dx.doi.org/10.1104/ pp.125.1.58. PMid:11154296.

LAWRENCE, B., 1984. A discussion of Schinus molle and Schinus terebinthifolius. Perfumer and Flavorist, vol. 9, pp. 65-69.

LEITE, A.C., BUENO, F.C., OLIVEIRA, C.G., FERNANDES, J.B., VIEIRA, P.C., SILVA, M.F.G.F., BUENO, O.C., 
PAGNOCCA, F.C., HEBLING, J.A. and BACCI JÚNIOR, M., 2005. Limonoids from Cipadessa fruticosa and Cedrela fissilis and their insecticidal activity. Journal of the Brazilian Chemical Society, vol. 16, no. 6, pp. 1391-1395. http://dx.doi.org/10.1590/ S0103-50532005000800015.

MALLIK, A.U., ZHU, H. and PARK, Y.G., 1998. Overcoming Kalmia induced growth in black spruce by micorrhizal inoculation. Journal of Korean Forestry Society, vol. 87, pp. 429-444.

MARASCHIN-SILVA, F. and AQUILA, M.E.A., 2005. Potencial alelopático de Dodonaea viscosa (L.) Jacq. Iheringia. Série Botânica, vol. 60, no. 1, pp. 91-98.

MARTINS, M.B.G.; CASTRO, A.A. and CAVALHEIRO, A.J., 2008. Caracterização anatômica e química de folhas de Jacaranda puberula (Bignoniaceae) presente na Mata Atlântica. Revista Brasileira de Farmacognosia = Brazilian Journal of Pharmacognosy, v. 18, n. 4, pp. 600-607. http://dx.doi.org/10.1590/ S0102-695X2008000400018.

MATOS, A.P., 2006. Busca de compostos inseticidas: estudo de espécies do gênero Trichilia (Meliaceae). São Paulo: Universidade Federal de São Carlos, 194 p. Tese de Doutorado em Química Orgânica.

MATOS, A.P., MYAMOTO, D.T., ALVES, A.R., LEITE, A.C., VIEIRA, P.C. and FERNANDES, J.B., 2010. Atividade de Cedrela fissilis e Cipadessa fruticosa (Meliaceae) sobre a lagarta-do-cartucho do milho Spodoptera frugiperda (JE Smith) (Lepidoptera: Noctuidae). BioAssay, vol. 5, no. 5, pp. 1-7. http:// dx.doi.org/10.14295/BA.v5.0.64.

MONTEIRO, J.M., ALBUQUERQUE, U.P., ARAÚJO, E.L. and AMORIM, E.L.C., 2005. Taninos: uma abordagem da química à ecologia. Quimica Nova, vol. 28, no. 5, pp. 892-896. http:// dx.doi.org/10.1590/S0100-40422005000500029.

MUNDIM, F.M., DIAS, M.S., TOGNI, P.H.B. and ALMEIDA, W.R., 2012. [viewed 08 September 2017]. Eficiência na defesa de embaúba Cecropia purpurascens (Urticaceae) por formigas associadas [online]. Available from: http://pdbff.inpa.gov.br/ cursos/efa/livro/2007/pdf/dimona/dim_po1g5.pdf

DEGANI, A.L.G., CASS, Q. B. and VIEIRA, P.C., 1998. Cromatografia: um breve ensaio. Química Nova na Escola, vol. 7, pp. 21-25.

PAES, J.B., DINIZ, C.E.F., MARINHO, I.V. and LIMA, C.R., 2006. Avaliação do potencial tanífero de seis espécies florestais de ocorrência no semi-árido brasileiro. Cerne, vol. 12, no. 3, pp. 232-238.

QUEIRES, L.C.S. and RODRIGUES, L.E.A., 1998. Quantificação das substâncias fenólicas totais em órgãos da aroeira Schinus terebinthifolius (Raddi). Brazilian Archives of Biology and Technology, vol. 41, no. 2, pp. 247-253. http://dx.doi.org/10.1590/ S1516-89131998000200012.

RICE, E.L., 1984. Allelopathy. 2nd ed. New York: Academic, 422 p. ROCHA, G.G., SIMÕES, M., LÚCIO, K.A., OLIVEIRA, R.R., COELHO KAPLAN, M.A. and GATTASS, C.R., 2007. Natural triterpenoids from Cecropia lyratiloba are cytotoxic to both sensitive and multidrug resistant leukemia cell lines. Bioorganic \& Medicinal Chemistry, vol. 15, no. 23, pp. 7355-7360. http:// dx.doi.org/10.1016/j.bmc.2007.07.020. PMid:17889544.

RODRIGUES, B.N., PASSINI, T. and FERREIRA, A.G. 1999. Research on allelopathy in Brazil. In: Narwal, S.S, ed. Allelopathy update. New Hampshire: Science Publishers, pp. 307-323.
SABBI, L.B.C., ÂNGELO, A.C. and BOEGER, M.R., 2010. Influência da luminosidade nos aspectos morfoanatômicos e fisiológicos de folhas de Schinus terebinthifolius Raddi (Anacardiaceae) implantadas em duas áreas com diferentes graus de sucessão, nas margens do Reservatório Iraí, Paraná, Brasil. Iheringia. Série Botânica, vol. 65, no. 2, pp. 171-181.

SANTOS, A.C.A., ROSSATO, M., SERAFINI, L.A., BUENO, M., CRIPPA, L.B., SARTORI, V.C., DELLACASSA, E. and MOYNA, P., 2010b. Efeito fungicida dos óleos essenciais de Schinus molle L. e Schinus terebinthifolius Raddi, Anacardiaceae, do Rio Grande do Sul. Revista Brasileira de Farmacognosia, vol. 20, no. 2, pp. 154-159. http://dx.doi.org/10.1590/S0102$695 \times 2010000200003$.

SANTOS-BUELGA, C. and SCALBERT, A., 2000. Proanthocyanidins and tannin-like compounds - nature, occurrence, dietary intake and effects on nutrition and health. Journal of the Science of Food and Agriculture, vol. 80, no. 7, pp. 1094-1117. http:// dx.doi.org/10.1002/(SICI)1097-0010(20000515)80:7<1094::AIDJSFA569 $>3.0 . \mathrm{CO} ; 2-1$.

SANTOS, P.M.L., JAPP, A.S., LIMA, L.G., SCHRIPSEMA, J., MENEZES, F.S. and KUSTER, R.M., 2010a. Antioxidant activity from the leaf extracts of Jacaranda puberula Cham., Bignoniaceae, a Brazilian medicinal plant used for blood Depuration. Revista Brasileira de Farmacognosia, vol. 20, no. 2, pp. 147-153. http:// dx.doi.org/10.1590/S0102-695X2010000200002.

SANTOS, R.B., LACERDA JÚNIOR, V. and CÂMARA, C.A.G., 2008. Caracterização fitoquímica do óleo essencial dos frutos de Schinus terebinthifolius Raddi. In: Resumos da XXXI Reunião Anual da Sociedade Brasileira de Química, 26-29 May 2008, Águas de Lindoia. São Paulo: Sociedade Brasileira de Química.

SANTOS, R.P., NUNES, E.P. and NASCIMENTO, R.F., 2006. Chemical composition and larvicidal activity of the essential oils of Cordia leucomalloides and Cordia curassavica from the Notheast of Brazil. Journal of the Brazilian Chemical Society, vol. 37, no. 4, pp. 556-560. http://dx.doi.org/10.1590/S010350532006000500030 .

SHIMIZU, M.T., BUENO, L.J.F., RODRIGUES, R.F.O., SALLOWICZ, F.A., SAWAYA, A.C.H.F. and MARQUES, M.O.M., 2006. Essential oil of Lithraea molleoides (Vell.): chemical composition and antimicrobial activity. Brazilian Journal of Microbiology, vol. 37, no. 4, pp. 556-560. http://dx.doi. org/10.1590/S1517-83822006000400028.

SIMÕES, V.N. and MINGUZZI, S., 2009 [viewed 08 September 2012]. Estudo fitoquímico e testes biológicos das folhas da Cecropia pachystachya Trec. Anais do ENIC [online], vol. 1, no. 1. Avaiable from: http://anaisonline.uems.br/index.php/enic/ article/view/1036

SOUZA, M.F., MANGOTTI, S.S., SOUZA, P.N.S., MEIRA, M.R. and MATOS, C.C., 2011. Influência do horário de coleta, orientação geográfica e dossel na produção de óleo essencial de Cordia verbenacea DC. Biotemas, vol. 24, no. 1, pp. 9-14.

STANGE, V.S., GOMES, T.D.U.H., ANDRADE, M.A. and BATITUCCI, M.C., 2009. Avaliação do efeito mutagênico do extrato hidroalcoólico bruto, por meio de bioensaios in vivo e prospecção fitoquímica de Cecropia glaziovii Sneth (embaúba), Cecropiaceae. Revista Brasileira de Farmacognosia, vol. 19, no. 2, pp. 637-642. http://dx.doi.org/10.1590/S0102-695X2009000400023.

SUBRAMANIAN, S., NAGARAJAN, S. and SULOCHANA, N., 1973. Hydroquinone from the leaves of Jacaranda mimosaefolia. 
Phytochemistry, vol. 12, no. 1, pp. 220-222. http://dx.doi. org/10.1016/S0031-9422(00)84658-0.

TAIZ, L. and ZEIGER, E., 2013. Fisiologia Vegetal. 5th ed. Porto Alegre: Artmed. 782 p.

TANAE, M.M., LIMA-LANDMAN, M.T.R., LIMA, T.C.M., SOUCCAR, C. and LAPA, A.J., 2007. Chemical standardization of the aqueous extract of Cecropia glaziovii Sneth endowed with antihypertensive, bronchodilator, antiacid secretion and antidepressant-like activities. Phytomedicine, vol. 14, no. 5, pp. 309-313. http://dx.doi.org/10.1016/j.phymed.2007.03.002. PMid:17434301.

ZAVAN, C., 2005. Identificação de inibidores de pectinase fúngica para o controle de formigas cortadeiras. Rio Claro: Universidade Estadual Paulista Júlio de Mesquita Filho, 96 p. Dissertação de Mestrado em Microbiologia.

WHITTAKER, R.H. and FEENY, P.P., 1971. Allelochemics: chemical interactions between species. Science, vol. 171, no. 3973, pp. 757-770. http://dx.doi.org/10.1126/science.171.3973.757. PMid:5541160. 